\title{
The Rise of Commercial Playing in 1540s London
}

The year 1576 is well-known to every historian of the English stage — in that year James Burbage and John Brayne built the Theatre in Shoreditch, traditionally considered the first custom-built playhouse in England, and around the same time several more playhouses sprang up in and around London. ${ }^{\mathrm{I}}$ Everything before that date is often lumped together as 'medieval' or 'Tudor', treated as an undifferentiated time of informal playing, taking place in open spaces such as markets and innyards until the playhouses came along. This assumption, however, considerably oversimplifies theatre history. Playhouses such as the Theatre were certainly a very important development, but they didn't arise from a vacuum, as William Ingram has pointed out; there had to have been a thriving commercial theatre scene in London already in the 1570 s if so many people were willing to invest money in it. ${ }^{2}$ As the following pages will argue, in London this commercial playing scene emerged suddenly in the I540s, a little more than 30 years before the Theatre. ${ }^{3}$

The term 'commercial playing', in the sense I am using it, refers to professional playing that is more independent and market-oriented than what had come before. The Records of Early English Drama project has demonstrated that at least some English players were being paid for performances in the fourteenth and fifteenth centuries, contrary to earlier 'evolutionary' narratives in which professionalism came only after the (amateur) civic cycle dramas. ${ }^{4}$ London certainly had professional playing in the fifteenth and early sixteenth centuries, but the evidence for it mostly involves civic drama tied to specific occasions, as described by Anne Lancashire in London Civic Theatre.5 Commercial playing, in contrast, is not specially commissioned or tied to a specific occasion, but rather performed by the players on their own initiative, with the anticipation (but not the guarantee) of making a profit. Instead of having a ready-made venue and audience, as at a livery company feast, such players also had to find a place to play and attract their own audience. At least in 
theory, they could play for an open-ended period of time and make as much money as the market (and the authorities) would allow.

\section{Proto-commercialism: John Rastell, Henry Walton and London Parish Playing, 1527-1532}

While true commercial playing in the above sense did not become prevalent in London until the late I530s and early I540s, a decade earlier a burst of what might be termed 'proto-commercialism' made apparent the possibilities of open-ended professional playing This playing involved John Rastell, the wellknown printer-playwright, and his associate, Henry Walton. Some of their activities have been known for more than a century because of a lawsuit from around I530, Rastell v. Walton, which was first printed in 1898.6 Recent discoveries, however, have revealed more information about Walton's theatrical activities, allowing us to put them in better context.

In 1527, John Rastell was hired to stage a pageant at the banqueting hall in Greenwich for the visit of the French ambassador on 4 May, for which he also wrote a dialogue and ordered numerous costumes. Around the same time, Rastell hired Henry Walton to build a stage on the property he had recently (in I524) started leasing near Finsbury Fields.7 Walton, a member of the Mercers' Company, in 1525 became the keeper of the Mercers' timberyard and surveyor of their building works, and probably worked on the pageant put on by the company for the 1526 Midsummer Show when mercer Sir Thomas Seamer was lord mayor. ${ }^{8}$ After the Greenwich pageant was over, Rastell lent the costumes to Walton, who frequently hired them out to players over the next three years, so that they became worn and damaged. Rastell eventually sued Walton in the court of requests to get the costumes back, probably in December 1530, and the resulting lawsuit provides much valuable information about playing conditions in London in the late 1520 . 9 The suit, however, provides no evidence as to where these plays took place, or to what extent they might be described as commercial in our sense.

Fortunately, newly published evidence from the Records of Early English Drama project sheds some light on the question. On 7 November 1527, the London court of aldermen granted All Hallows London Wall parish, and no other parish, a licence to put on stage plays from Easter to Michaelmas I528, to raise money for repairing the church. ${ }^{10}$ The churchwardens' accounts further reveal that the parish made a total profit of $£ 58 \mathrm{~s} 9 \mathrm{~d}$ on the plays, and that it hired 'harry walton' to build the stage, since afterward it paid him $7 \mathrm{~s}$ 
$6 \mathrm{~d}$ 'that he layd owt for bord' and half of the $8 \mathrm{~s}$ 'that he layd owt for nalles'. ${ }^{\text {II }}$ On 20 April 1529 the court of aldermen granted permission for St Katherine Cree parish to put on plays of its own until the following Michaelmas, again with the provision that no other parish could put on plays during that time. ${ }^{12}$ Unfortunately, the St Katherine Cree churchwardens' accounts do not survive from this period, so we do not know whether they also hired Walton.But the following year another parish, St Botolph without Aldersgate, received 3s 4d 'of Walton $\&$ his ffelowes for the huyre of the Church yarde to play in oone' and IIs $6 \mathrm{~d}$ 'receyuyd $\&$ gatheryd At A play in the Churchyarde the which play the seid Walton by Couenante gaue vnto the Church'. ${ }^{13}$ Here we see Walton leading a company of players, or at least being perceived as their leader, suggesting that he was producing the plays.

Given Walton's involvement with these benefit plays, it seems likely that these were the plays in which John Rastell's costumes figured over the threeyear period from 1527 through I530. George Maller, a king's player who testified in the lawsuit, estimated that Walton lent the costumes out for 20 performances a year, a number consistent with one performance a week between Easter and Michaelmas. These were not true commercial plays in our sense, since they were licensed by the city government for specific time periods with profits going to the churches, but the fact that they were able to attract an audience and make such a substantial profit surely did not go unnoticed. ${ }^{14}$ Walton may have helped out with the Midsummer Show pageants put on by the Mercers in 1536 and 1537 (when two members of the Mercers were sequentially lord mayor), perhaps lending his costumes for the occasions. ${ }^{15}$ After he died in debt (and possibly in prison) in late 1539 or early 1540, an inventory of Walton's goods taken on I5 April 1540 included 'a greatt Chest wherin the players garmentys lye' and five tiers of garments hanging in his bedroom with caps, beards, and wigs. ${ }^{16}$ All this evidence suggests that Walton was a 'property player', a type of entrepreneur in sixteenth-century England who was hired (often from London by towns or parishes in the surrounding counties) to produce plays, provide costumes, help with the building of sets, and arrange anything else needed for dramatic productions. ${ }^{17}$

\section{The Dawn of Commercialism: Evidence from London Livery Companies}

The first good evidence of true commercial playing in London starts to appear about a decade after Henry Walton's parish plays. It comes in two main, 
complementary strands - evidence of players paying to rent out playing venues such as livery company halls, and evidence of city authorities trying to suppress or control independent plays being performed outside the traditional channels. Both types of evidence are unknown before the late I530s, but become quite common in the I540s.

Some London livery companies began to record payments to players in the early fifteenth century, shortly after the end of the cycle plays that had been performed semi-regularly at Clerkenwell, northwest of the city proper, for some 200 years. ${ }^{18}$ Livery companies typically hired players in conjunction with the annual (or biennial or triennial) feasts at which they chose and inducted new officers, and sometimes also at such feast times as Christmas and Candlemas. Several companies preserve annual records of payments to players over many years in the fifteenth century, and such dramatic activity became more common in the first half of the sixteenth century as more livery companies became wealthy enough to afford halls and regular feasts. The regular schedule of company feasts would have provided a fairly predictable source of income for a small number of professional players in London in the early sixteenth century.

What changed in the late I53Os was that, instead of making payments to players, companies started receiving payments from players for the use of their company halls. Instead of waiting for company feasts which might (or might not) offer a paying job, some players were hiring out company halls in order to perform plays on their own terms for a paying audience. The earliest such record that has come to light involves the Armourers, who received I2d in I537-38 'for a play kepte in our hall'. ${ }^{19}$ The players were probably familiar with Armourers' Hall from having already played there, since another record shows that 'baldock ye player' was present at an Armourers' dinner in October $154 \mathrm{I} .{ }^{20}$ As it happens, the hall in question is well documented, since it survived the 1666 Great Fire, and a detailed plan made in I679 still survives in the Guildhall Library. It was located on Coleman Street in the northernmost part of the city near Moorgate, on the same site as the Armourers' present hall. The I679 plan shows that the Great Hall, where plays were presumably performed, was about 50 feet long and 22 feet wide, and an accompanying description says that it was floored with boards and wainscotted round. ${ }^{21}$ This size was slightly smaller than other playing venues from this period whose dimensions are known, such as the original Inner Temple Hall (70 feet by 29 feet) and the Old Hall at Lincoln's Inn (originally 60 feet by 32 feet). ${ }^{22}$ The original Armourers' Hall survived until 1840 , when it was torn down and 
replaced with a new hall, which survived the Blitz in 1940 and still stands today. ${ }^{23}$

Playing in livery company halls must have continued with some frequency, because in the spring of 1542 the London city authorities moved to suppress it as part of a general wave of repression, mostly aimed at protestant reformers. ${ }^{24}$ On II April 1542, Lord Mayor Michael Dormer ordered the aldermen to prevent 'any commen playes or enterludes' within livery company halls, the first of many times in the sixteenth century when the London authorities tried to suppress or control plays. ${ }^{25}$ Six days later, Edmund Bonner, bishop of London, issued an injunction prohibiting all 'common plays or interludes' in churches or chapels. ${ }^{26}$ Such attempts at suppression proved futile, however, for the rest of the decade shows players repeatedly renting the halls of the Weavers and the Founders, two of the companies whose financial records from this period happen to survive. In 1544 the weavers received I6d 'off Wyllyam Teysdaile for playng in our hall', and the same year the founders received Ios $4 \mathrm{~d}$ 'of players for playing in the hall' and another Ios 'of playars for playing in the hall'. In 1545 the Founders received 2Is 8d 'for playing in the hall, from Seynt Nycholas day tyll after Chrystmas'; in 1546 the Weavers received 6s 'of Players for playng in howr halle'; in 1547 the Founders received I6d 'for a pllay in the all', and two years later they received I4s $2 \mathrm{~d}$ 'for playinges $\&$ weddinges in the hall, with the Watterbearers' feast'. ${ }^{27}$ Both the Weavers and the Founders appear to have charged players I6d for the use of their hall for a single play, more than the I2d charged by the Armourers in the previous decade; if this fee was approximately the standard rate, it implies that players rented out Founders' Hall I5 or I6 times in both I544 and I545. If we conservatively estimate an admission charge of a halfpenny, an audience of at least 30 to 40 would have been needed to break even.

Unfortunately, we know much less about either of these halls' physical structures than we do about Armourers' Hall. Weavers' Hall was located in St Michael Bassishaw parish, just northeast of the Guildhall. It was created out of two adjacent tenements which the company had purchased on 22 December 1498 for $£ 23$ 6s $8 \mathrm{~d}$ from John Hart. The company paid for repairs to the hall numerous times in the 1530 and I540s, but around I550, soon after it had been used by the players, the Weavers decided to build an entirely new hall on the same site, a project that lasted until $1563 .{ }^{28}$ This new hall burned in the Great Fire a century later, and its successor is shown in the 1676 Ogilby and Morgan map as being irregularly shaped, about 90 by 80 feet at its longest and widest points, with a small yard near the entrance and a garden in the 
middle. The larger northern part of the building could have encompassed a great hall up to 70 by 40 feet in size, but it would be rash to assume that the dimensions of the 1676 building were necessarily the same as in the earlier version from 130 years earlier. ${ }^{29}$

As for the founders, their hall was located in Brode Alley, north of Lothbury in the parish of St Margaret Lothbury. The company had purchased the property, consisting of two messuages and a garden, from the grocers in I53I and had converted it into their hall by 1535 , though the site also contained four tenements that the company let out for a total rent of $£_{3}$ os $8 \mathrm{~d} . .^{30}$ This hall, like the weavers' original hall, burned in the Great Fire but was quickly rebuilt. The 1676 Ogilby and Morgan map shows the new hall as being roughly 75 feet long east-west and 32 feet wide at its widest point, with a large garden to its west and the St Margaret Lothbury churchyard to its eaSt ${ }^{3 \mathrm{I}}$ This hall was frequently hired over the next one hundred and fifty years by a variety of bodies, including other livery companies and a dancing master. It was on the upper floor, accessible by a flight of stairs. Although a new hall replaced it in 1844, in 1877 the Founders let it out to the Electric Telegraph Company and moved to a new hall in St Swithin Lane. ${ }^{32}$

\section{Evidence from London Civic Authorities, I54I-I543}

Parallel to all this evidence of commercial playing in London livery company halls in the I540s, we find evidence of London civic authorities trying to control or suppress unofficial playing in the city. This new phenomenon seemed to accompany the practice of players renting out company halls. The proceedings of the common council (the journals) survive from 1416 , the proceedings of the court of aldermen (the repertories) survive from 1495 , and less detailed records from both bodies (the letter books) survive from I275. These records show the London authorities frequently trying to control tennis, bowling, football, and other pastimes in the late fifteenth and early sixteenth centuries, but before 1540 the only references to dramatic activity are proclamations against 'mummyng' at Christmastime in I4I7 and $145 \mathrm{I}^{33}$

As noted above, the earliest antitheatrical efforts recorded in these volumes is the April 1542 lord mayor's proclamation against playing in company halls, which was closely followed by the bishop of London's prohibition against plays in churches. These proclamations may have been motivated by a protest by the bishops against 'the contempt of God's Word' in plays, made in the Canterbury Convention the previous month. ${ }^{34}$ Religious controversies were a 
constant presence in these early days of commercial playing in London, amid the wrenching changes initiated by Henry VIII and his break with Rome. Two decades later martyrologist John Foxe, in his Actes and Monuments, claimed that in I54I in Shoreditch, 'Shermons, Keeper of the Carpenter's Hall in Christ's parish, was presented for procuring an interlude to be openly played, wherein priests were railed on and called knaves'. 35 No contemporary record of this event survives, and it is not clear exactly what location Foxe is referring to; it is apparently not the Carpenters' company hall, which has been located in Allhallows London Wall parish since the early isth century. ${ }^{36}$

The spring of 1543 saw another crackdown on playing by the London authorities, also with religious overtones. On 30 March, the mayor and recorder complained to the privy council about 'eating off flesshe in the Lent' as well as 'the licentiows manner off playours', and on io April, the privy council committed to ward twenty joiners who had made a disguising on a Sunday morning, plus four players of the lord warden who had played contrary to orders. ${ }^{37}$ On I April, the common council made Ambrosius Chapman, citizen and draper, sign a bond saying that he would no longer stage any disguisings or plays in 'a certayn yard or voyd growne called the Carpenters yard in the parishe of saint Botolf in london'. ${ }^{8}$ On 2 April, the court of aldermen issued an order suppressing all plays in the city because somebody had been setting up playbills on the lord mayor's gate 'ageynst doctour wylson $\&$ doctor weston', apparently referring to Nicholas Wilson, prebendary of Hoxton, and Hugh Weston, rector of St Nicholas Olave. Both of these men were conservative Catholics, so the plays mocking them were presumably Protestant in nature. ${ }^{39}$ The aldermen also ordered 'bylls for playes or interludes wythin this Cytye' to be pulled down, and singled out three citizens to sign $£ 40$ bonds saying they would no longer permit interludes or common plays in their 'dwelling houses'. These citizens were William Blytheman, citizen and clothworker, who was not to allow plays 'within hys dwelling house called the Erle of Northumberlondes place'; George Tadlowe, citizen and haberdasher; and Thomas Hancock, citizen and vintner. ${ }^{40}$

These are clearly commercial performances in our sense. Chapman is said to have 'allure[d] \& gather[ed]' a 'multytude of people' to Carpenter's Yard, and the second record specifically tries to suppress playbills, the main means by which commercial players advertised their performances and attracted an audience. (This record is, in fact, the earliest known reference to playbills in England. ${ }^{\mathrm{I}}$ ) The specific mentions of 'the Carpenters yard' and 'the Erle of Northumberlondes place' give us two of the places (besides livery com- 
pany halls and churches) where actors performed commercial plays, and the involvement of Thomas Hancock and George Tadlowe indirectly point to two other places. The nature of the order against Blytheman, Tadlowe, and Hancock - in specifically objecting to bills which were posted against conservative Catholic clergymen (Wilson and Weston) and which suppressed plays in the city on that account - suggests that these men had pro-Protestant, anti-Catholic sympathies, and their biographies (especially those of the latter two) support this idea. Much of the information in the following sketches comes from before or after 1543 , but it provides crucial evidence about the size, shape, and general character of possible playing spaces, as well as the social context underlying these early days of commercial playing. ${ }^{42}$

\section{Ambrose Chapman and Carpenter's Yard}

First, let us consider Ambrose Chapman, citizen and draper. He had been attracting people to plays in a yard or voyd growne called the Carpenters yard in the parishe of saint Botolf in london', said to have been 'Late in the tenure of one Gray carpenter deceassed'. This carpenter was John Gray, a freeman of the Carpenters' Company who was also a brewer by profession. ${ }^{43}$ Gray's will (dated I3 October I542) and two later lawsuits reveal that he was leasing several different London properties at his death in late 1542.44 He was leasing Carpenter's Yard and the surrounding buildings from the lepers' hospital of Burton Lazars, Leicestershire, a religious house, which the crown seized right around the time we are discussing, certainly by $1544 .{ }^{45}$ In addition, the seizure included a building called the Green Dragon in Cow Lane, St Sepulchre without Newgate; two tenements in nearby Hosier Lane; and a brewhouse called Watts Brewhouse in Fryer Lane, near Thames Street in Allhallows the Great parish, which Gray was leasing from Richard Watts, and which he had recently spent $£ 40$ expanding and renovating. Gray and his wife Elizabeth were living in Allhallows the Great at the time of his death, but they had only recently moved there from St Sepulchre (where he asked to be buried), presumably to renovate and run the brewhouse. ${ }^{46}$

Gray bequeathed Carpenter's Yard to Elizabeth in his will, but he also left considerable debts, possibly resulting from the brewhouse project. The will provided that the lease of the Green Dragon should be sold to pay these debts, but this did not happen; instead, in early 1543 Elizabeth became engaged to marry Ambrose Chapman, who, along with his brother Robert Chapman, citizen and merchant taylor, promised to pay John Gray's debts. For that 
reason, Ambrose Chapman came to control Carpenter's Yard when plays were being performed there that spring; in fact, the plays may have been an attempt to raise money toward repaying the debts. Chapman had been freed as a Draper just two years before, in I54I, so he was most likely fairly young. 47 He died, however, before the wedding could take place, leading to several lawsuits over the disposition of John Gray's estate and debts..$^{4}$ Elizabeth Gray still held the lease to both the Green Dragon and Carpenter's Yard (but not Watts Brewhouse) when she made her own will on 22 August 1546.49

Unfortunately for our purposes, none of this documentation gives much useful information about the physical description of Carpenter's Yard, or even its exact location. One of the lawsuits appears to say that it was in Cow Lane, the same street as the Green Dragon, which would put it in St Sepulchre's parish. The common council record says that it was in 'the parishe of saint Botolf in london', presumably St Botolph Aldersgate, to the east of St Sepulchre's, the same parish in whose churchyard Henry Walton had been putting on benefit plays a dozen years earlier. ${ }^{50}$ The 1676 Ogilby and Morgan map shows a Carpenter's Yard in St Botolph Aldersgate south of Little Britain, about 40 feet long and 25 feet wide, with entrances from three directions, in an area that (barely) survived the Great Fire. ${ }^{5 \mathrm{I}}$ On the other hand, numerous places called 'Carpenter's Yard' existed in London and we cannot assume that this Carpenter's Yard is the one from I543, especially given how much the city had changed in 130 years.

\section{William Blytheman and Northumberland Place}

Next we have the three citizens targeted by the court of aldermen on 2 April I543, the day after the common council targeted Ambrose Chapman. The first of these was William Blytheman, citizen and clothworker, who was not to allow plays 'within hys dwelling house called the Erle of Northumberlondes place'. Northumberland Place or House was located just inside Aldersgate in St Anne and St Agnes parish, where William Blytheman lived for at least I5 years. ${ }^{52}$ He became free of the Clothworkers' Company in I 532 and soon afterward bought property in Richmond, Surrey and Brainford, Middlesex from the heir of a minor court official, suggesting some court connections. 53 Our William Blytheman does not appear in the 1536 subsidy assessment for that parish, but in I54I he was assessed on $£ 20$ of goods in the parish, and in the 1547 assessment he was assessed on $£$ IOO of goods. ${ }^{54}$ Blytheman stopped paying quarterage dues to the Clothworkers after 1543, around the time of 
his run-in with the court of alderman, but it is not clear if the two events are related; in any case, he continued to live in the parish and call himself 'citizen and clothworker'.

The history of Northumberland Place is well documented from the midfourteenth century onward. It was long owned by the Percy family, which included the earls of Northumberland, but it was seized by the crown numerous times when the Percies were out of royal favor. The period when William Blytheman was hosting plays there was one of those times. 55 The building had been part of the estate of Henry Algernon Percy, sixth earl of Northumberland, but in the early I530s he was forced to sell off his estate piecemeal because of heavy debts, ill health, and a failed marriage. ${ }^{56}$ On 3 August I534, the earl leased Northumberland Place for 2I years to William Paget (then clerk signet, later comptroller of the king's household), and sold the reversion of the property to the crown. ${ }^{57}$ Shortly before the earl's death on 29 June I537, Henry VIII seized all of his estates, but the leases remained in effect; thus, when plays were being performed at Northumberland Place in the spring of I543, Blytheman was subleasing it from Paget, who was leasing it from the crown. The Percy family eventually regained ownership of the property on I6 August 1557, when Philip and Mary granted the sixth earl of Northumberland's former estates, explicitly including Northumberland Place, to his nephew Thomas Percy, the newly restored seventh earl..$^{8}$ The building was later leased to the royal printer, Robert Barker, who in I6II printed the first edition of the King James Bible there, and eventually it became an inn called the Mouth, later the Bull and Mouth, which burned in the Great Fire but was soon rebuilt.59 The Bull and Mouth inn was one of the most famous in London until it was torn down in I888 to make room for an extension of the General Post Office. ${ }^{60}$

Northumberland Place is often described in early documents as an 'inn' with eight to twelve attached shops. The 1676 Ogilby and Morgan map depicts the rebuilt version as having a substantial yard, 56 by 56 feet at its widest points, and it is tempting to think that William Blytheman's plays may have been performed there 133 years earlier. ${ }^{61}$ Other documents, however, show that the pre-Fire building had a hall on the east side of the yard, and an anecdote from a 1567 jest-book suggests that plays were being performed in this hall in the $1560 .^{62}$ The anecdote involves a confidence man, Qualitees, putting up bills to lure people to a non-existent play at Northumberland Place, then absconding with the takings. After the crowd has gathered, giving a penny or half-penny apiece to two gatherers hired to stand at the gate, 
Qualitees takes the money from the gatherers and 'bade them go into the hall, and see the rome kepte: for hee shoulde gooe and fetche the plaiers', after which he takes horse outside Aldersgate and rides away. The gate where the gatherers stood is probably the one leading into the yard, but the play was apparently going to take place in the hall. ${ }^{63}$ Of course, plays at Northumberland Place may have been performed in the yard in 1543 and in the hall in 1567 , but at the very least this anecdote shows that a building with a yard might still host plays indoors in a hall.

\section{George Tadlowe and the White Horse}

The second man targeted by the aldermen on 2 April 1543 was George Tadlowe, citizen and haberdasher. Tadlowe was a prominent London citizen with many interesting connections, by far the best-documented of the four men accused of hosting plays in the spring of $1543 .{ }^{64} \mathrm{He}$ was born about I488, and by the 1520 s he had become quite wealthy as a merchant and moneylender, frequently lending large sums of money to his fellow merchants and eventually investing in some of their ships. ${ }^{65}$ He lost most of this wealth in the midI530s due to 'Dyvers misfortunes of Shippewracks' and was briefly imprisoned in 1536 over a debt, but he eventually recovered from this debacle. ${ }^{66}$ Tadlowe had started leasing the White Horse tavern in Lombard Street by at least 1532, and for the next twenty years he was a prominent resident of St Mary Woolnoth parish, where the tavern was located, while supporting Protestant causes. ${ }^{67} \mathrm{He}$ was assessed on $£ 40$ of goods in the 154I London subsidy assessment and on $£ 30$ in 1549 ; he was a churchwarden from 1542 to I544 (including the period when he was hosting plays); and he is named in the parish register four times from 1545 to $1552 .{ }^{68} \mathrm{He}$ served in parliament four times between 1547 and 1555 , and as a London common councillor in I549, he made a speech in support of Lord Protector Somerset that was later printed in Foxe's Actes and Monuments and Holinshed's Chronicle. ${ }^{69}$ In I55I he persuaded Raphe Robinson to publish the first English translation of More's Utopia, leading Robinson to praise Tadlowe as 'a man of sage, $\&$ discret witte' while criticizing the Catholic martyr More. ${ }^{70} \mathrm{He}$ died in St Mary Woolnoth in 1557 , but was buried in St Magnus alongside his first wife; Henry Machyn described Tadlowe's funeral in his famous diary. ${ }^{71}$

Although the White Horse tavern was not named in the aldermen's order, it was presumably the 'dwelling house' in which Tadlowe had been hosting plays. The White Horse was a large building with entrances on both Lom- 
bard Street to the north and Sherborne Lane to the southwest, directly to the east of the St Mary Woolnoth parish church. Tadlowe originally leased the White Horse from the Minoresses without Aldgate, who had owned it since I32I, but in I539 Henry VIII seized all of the abbey's property and sold the St Mary Woolnoth block, including the White Horse, to Martin Bowes, future lord mayor and resident of the parish. ${ }^{72}$ The White Horse remained a popular tavern until after the Restoration, being frequently visited by Pepys in the I66os, but after it burned in the Great Fire and was rebuilt, the building was taken over by wealthy banker Sir Robert Viner for other purposes. ${ }^{73}$ The 1676 Ogilby and Morgan map depicts 'Sir Robert Viner's House' as an inn-like structure with a large central yard, about 56 feet long from north to south and 32 feet wide from east to west, accessible via a 50-foot covered passageway from Lombard Street. In the southern part, there is another wide covered passageway from Sherborne Lane, leading to another, smaller courtyard, about 36 by 30 feet, and two alleyways. The whole building was about I5O feet long at its eastern edge and about Ioo feet wide at its widest point, near the southern edge of the main courtyard. ${ }^{74}$ In 1678 Viner leased the building to the city of London for use as the General Post Office, which it remained into the 19th century. ${ }^{75}$ In his 1720 Survey of the Cities of London and Westminster, John Strype says of the Post Office that it was 'built by Sir Robert Vyner Goldsmith, Alderman of the City of London, Knt. and Bart. on the Ground, where stood a great Tavern before the Fire', and in I79I Thomas Pennant similarly wrote that 'a much-frequented tavern' stood on the Post Office site before the fire. ${ }^{76}$

\section{Thomas Hancock and the Bishop's Head}

Finally we come to Thomas Hancock, citizen and vintner, the third man who had to sign a bond in 1543 promising that he would no longer host plays. Hancock was born about 4999 and became a freeman of the Vintners' Company on 28 July 1530 after serving an apprenticeship with Alan King. ${ }^{77} \mathrm{He}$ served as a warden of the Vintners in 1548 and 1555 , freed apprentices in 1549 , I55I, and 1554, and bound three apprentices in 1556, all of whom were eventually freed..$^{78} \mathrm{He}$ was an active resident of St Mary Woolnoth from at least the late 1530 onward. Ten of his children appear in the parish register between I539 and I55I; he was taxed on $£ 20$ of goods in the I54I assessment and on $£ 30$ in I549; and he served as a churchwarden from 1546 to 1548 , two years after George Tadlowe's term. ${ }^{79}$ Though no contemporary record explicitly states 
where in the parish Hancock lived and did business, Hancock later testified that in 1543 he had been dwelling at the Pope's Head, a tavern directly across Lombard Street from Tadlowe's White Horse, and presumably it was at that tavern that he was hosting plays. $^{80}$

The Pope's Head had long been one of the largest and most popular taverns in London. The building is documented from the late thirteenth century, and it was a tavern by at least I4I5, when it was described as 'hospicium'. ${ }^{81}$ On 22 May 1517 it was purchased (along with adjacent properties) by George Monoux, alderman and former lord mayor of London, and on I July 1537, Monoux granted these properties to his grand-nephew Thomas Monoux of Walthamstow, Essex, then leased them back a week later for a term of 40 years. Thomas Monoux died on 4 December 1537, leaving the properties to his eight-year-old son George, and an inquisition post mortem taken on 27 October 1538 enumerated them, including the messuage called the Poppeshed'. ${ }^{82}$ Thus, at the time he was hosting plays in I543, Thomas Hancock was subletting the Pope's Head from the elder George Monoux, who was leasing it from his great-grandnephew, also named George Monoux. The elder George Monoux's will was proved on 28 March I544, seven weeks after his death on 9 February; among many other bequests, he left to William Monoux, the eight-year-old second son of Thomas Monoux of Walthamstowe, leases for lands and tenements in Lombard Street and Cornhill, 'wherof the principall tenement is cauled the popes hedd otherwise cauled the busshoppes hedd'. ${ }^{83}$ On 23 April and I May 1554, the younger George Monoux, now a married man living in London, sold 'Taberna nuper vocat $a$ le popes head et modo vocat $a$ le Busshoppes head' [a tavern formerly called the Pope's Head and now called the Bishop's Head] to Thomas Hancock and his wife Marie, who occupied the property. ${ }^{84}$

Presumably Hancock changed the tavern's name from the Pope's Head to the Bishop's Head around 1540, consistent with his hosting anti-Catholic plays there in the spring of 1543 . A further bit of suggestive evidence comes from the fact that on 20 February I554, two months before they bought the Bishop's Head, Hancock and his wife also bought a house and two gardens in St Katherine Coleman, a parish known as an enclave for radical Protestants. ${ }^{85}$ When Mary took the throne in 1553 and reinstated Catholicism, St Mary Woolnoth re-embraced the old faith with particular vigor, paying for boats to retrieve the parish's ornaments from Westminster and for the royal receiver to hunt down two tabernacles it had previously owned ${ }^{86}$ In this environment St Katherine Coleman may have seemed a more hospitable par- 
ish for Protestants, and a few months later Hancock bought his house there. He disappears from the St Mary Woolnoth parish register after 1552, despite remaining active in the Vintners' Company and elsewhere, suggesting that he leased out the Bishop's Head and moved to the new parish.

The Pope's Head (as it was again known by the late sixteenth century) was set back from Lombard Street behind some shops, and was accessible from Pope's Head Alley, which went all the way through to Cornhill on the north; a description in John Stow's 1598 Survey of London says that it was 'strongly builded of stone'. ${ }^{87}$ A detailed 1659 ground plot of the pre-Fire Pope's Head shows that the ground floor of the tavern was mostly on the west side of Pope's Head Alley, and was 36 feet wide (east-west) at its widest point by 67 feet 2 inches long (north-south) at its longest point. ${ }^{88}$ This ground floor included a small yard (too small for plays to have been performed in), a large kitchen, a bar, and three parlors; the upper floor (described but not shown on the ground plot) had drinking rooms on both the east and west sides, connected by a wide passageway over Pope's Head Alley below.A schedule lists fourteen rooms in the tavern as a whole; assuming that four of these plus the 'Kitching' correspond to the rooms depicted on the ground plot, nine rooms, some of which could have been fairly large, were in the tavern's upper level,. Very likely, plays at the Pope's Head would have been performed somewhere on this upper level. The Pope's Head was destroyed in the Great Fire but quickly rebuilt. It remained a popular tavern throughout the eighteenth century and into the nineteenth, and in I884 it became Short's Wine House, which it remained until the building was demolished in 1926 to make room for the new headquarters of Lloyd's Bank. Photographs from the late nineteenth or early twentiethth century, when Short's occupied the former tavern, depict an imposing stone building. ${ }^{89}$

\section{Commercial Playing in London, 1545-1549}

For the rest of the decade the London authorities continued trying to suppress or control commercial playing in the city, though without ever providing another bonanza of evidence like that of I543. On I2 January I545, the court of aldermen ordered the earl of Hertford's players not to play any more interludes in London except in the houses of the lord mayor, sheriffs, aldermen, or other substantial citizens. $9^{\circ}$ The earl of Hertford was Edward Seymour, uncle of the future Edward VI and doomed future lord protector; given the earl's religious inclinations, it seems likely that his players were presenting 
Protestant plays. A few weeks later on 6 February, the city issued a proclamation against interludes and common plays that were being 'more commonly $\&$ besylye set foorthe and played then heretofore hathe bene accustomed'; such plays were only to be allowed in the houses of prominent citizens or 'head parishioners', in open streets 'as in tyme paste it hathe bene vsed \& accustomed', or in livery company halls 'at the Request $\&$ desyre of the same Companyes ... in theire commen assembles ... and in none otherwise'. ${ }^{\mathrm{I}}$

This proclamation neatly summarizes the recent changes in how players had been behaving, and expresses the authorities' frustration at their inability to control those changes. The players had been presenting interludes and common plays 'more commonly $\&$ besylye ... then heretofore hathe bene accustomed', and were doing so not in the open streets, as with the civic pageants that John Rastell and Henry Walton had helped with twenty years earlier, but in taverns, halls, and enclosed yards where they could charge admission. The players were also performing in livery company halls, but on their own initiative, not 'at the Request $\&$ desyre of the same Companyes ... in theire commen assembles', as had always been the case before. The list of places where plays were to be allowed is fairly inclusive, reflecting the new realities (George Tadlowe and Thomas Hancock would presumably have counted as head parishioners'), but it at least tries to impose some limits. Just about the only new feature of London playing that this proclamation did not try to control is playbills, but they were covered later on 17 March 1547, when the court of aldermen ordered the beadles of each ward to pull down playbills of 'commen players' each Sunday morning and bring them to the lord mayor. ${ }^{92}$

In 1549 , the repertories provide a few more glimpses of London commercial playing, though these do not add much to what we already know. On 27 May, the court of aldermen ordered livery companies not to allow their servants or youths to make any May games or resort to plays. The same day, the aldermen ordered John Wilkinson, currier, 'who comenly suffreth \& meynteyneth interludes \& playes to be made and kept within his dwelling house', not to allow any more such plays. ${ }^{93}$ Unfortunately I have not been able to identify where John Wilkinson's house was in 1549, and nobody of that name appears in the I54I subsidy assessment. The records of the Curriers' Company, which survive from 1556 , show that Wilkinson was a warden of the company in $1559-60,1564-65$, and 1570 , dying in office in the latter year. ${ }^{94}$ In his will, dated 2I September 1570, Wilkinson calls himself 'Citezen and Corryer of London' and asks to be buried in St Thomas, Southwark, where he was apparently living. ${ }^{95}$ This might seem to point toward early playing in 
Southwark, but we cannot assume that John Wilkinson had been living in St Thomas Southwark 2I years earlier when he was hosting plays. Unfortunately, that parish's records do not survive from this period, our John Wilkinson does not seem to have been litigious, and so we are left with frustrating gaps in our knowledge.

On 4 July 1549, the court of aldermen asked the lord mayor to ask the lord chancellor for help with 'the steyinge of all comen interludes \& pleyes within the Citie \& the suburbes therof', and on 7 November they ordered the two secondaries of the counters, Mr. Atkyns and Mr. Burnell, to 'pervse all suche enterludes as hereafter shalbe pleyed by eny comen pleyr of the same within the Citie or the liberties therof' ${ }^{96}$ In this latter record we see the first attempts at the formal censorship of plays that would become so organized later in the century. In fact, almost exactly 25 years later, on 6 December 1574, the common council issued a much more elaborate order for controlling plays in the city, one that contributed indirectly to the building of the first custom-built playhouses over the next few years. ${ }^{97}$ Commercial playing in London had continued to grow during that intervening quarter-century, with such developments as the use of London inns for plays starting in the 1550 s. But the foundations for all this had been laid in the I54OS when commercial plays exploded onto the London scene, and both players and authorities started negotiating the ultimate paradigm for this new business of commercial playing.

\section{Notes}

Many details of these playhouses are collected in Herbert Berry, 'Playhouses, I560I660', in Glynne Wickham, Herbert Berry, and William Ingram (eds), English Professional Theatre, I530-I660 (Cambridge, 2000), 287-418. Of course, the Theatre was preceded by the short-lived Red Lion in 1567 , but that does not change its importance in the history of English professional theatre.

William Ingram, The Business of Playing: The Beginnings of the Adult Professional Theater in Elizabethan London (Ithaca and London, 1992).

An earlier, condensed version of this paper was presented at the 43rd International Congress on Medieval Studies in Kalamazoo, Michigan, in May 2008. Many of the key playing records cited in the following pages were summarized in Ian Lancashire, Dramatic Texts and Records of Britain: A Chronological Typography to I558 (Toronto, 1984), 197-208, though the details about people and buildings are largely new. This 
material is part of a larger project documenting inns, taverns, halls, and other places besides playhouses where plays were performed in sixteenth-century London. I plan to present the results of this research in a forthcoming book, which will include much more detail about the people and buildings discussed in the present paper.

4 John Wasson, 'Professional Actors in the Middle Ages and Early Renaissance', Medieval and Renaissance Drama in England I (1984), I-II.

5 Anne Lancashire, London Civic Theatre (Cambridge, 2002). Such occasions included annual events such as the Midsummer Watch and livery company feasts, and onetime events such as royal entries.

6 Henry Plomer, 'New Documents of English Printers and Publishers of the Sixteenth Century', Transactions of the Bibliographical Society 4 (1898), I53-83; reprinted as 'Pleadings from a Theatrical Lawsuit. From the Records of the Court of Requests. John Rastell v. Henry Walton.' in Alfred W. Pollard (ed.), Fifteenth Century Prose and Verse (Westminster, 1903), 307-2I. The lawsuit is transcribed more completely and accurately in Janette Dillon, 'John Rastell v. Henry Walton', Leeds Studies in English 28 (1997), 57-75 and Mary Erler (ed.), Records of Early English Drama: Ecclesiastical London (Toronto, 2008), 74-85, and is discussed in Janette Dillon, 'John Rastell's Stage', Medieval English Theatre 18 (1996), I5-45, and Ingram, The Business of Playing, 7I-2.

7 The two most thorough discussions of this stage are Dillon, 'John Rastell's Stage', and A.W. Reed, Early Tudor Drama: Medwall, the Rastells, Heywood and the More Circle (London, 1926), 230-3.

8 See Erler, Ecclesiastical London, 365, citing Anne Sutton, The Mercery of London: Trade, Goods, and People, II30-I578 (Aldershot, 2005), 387-8. The Mercers' records concerning the 1526 Midsummer Show are in Jean Robertson and D.J. Gordon, A Calendar of Dramatic Records in the Books of the Livery Companies of London, I485-I640 (Oxford, 1954), I7-18.

9 The National Archives (henceforth TNA), REQ 2/8/I4.

Io This record was printed first by Charles Welch (ed.), The Churchwardens' Accounts of the Parish of Allhallows, London Wall, in the City of London (London, 1912), 57-8, and later by E.K. Chambers (ed.), 'Dramatic Records of the City of London: The Repertories, Journals, and Letter Books', in Malone Society Collections, vol. 2, part 3 (Malone Society, 1931), 287; it is also transcribed by Erler, Ecclesiastical London, $225-6$.

II Erler, 68, transcribing Guildhall Library MS 5090/I, f.42v.

I2 Chambers, 'Dramatic Records', 287-8, and Erler, Ecclesiastical London, 226-7.

I3 Erler, 85 and 369-70, transcribing Guildhall Library MS I454/47, sheet 4. 
I4 Paul Whitfield White (personal communication) notes that the distinction between amateur and professional playing could be blurry in parish settings such as those discussed in this section, since parishioners outside London would sometimes put on plays in the local church and even take them on tour to surrounding communities, turning over any profits to their local churchwardens. See Paul Whitfield White, Drama and Religion in English Provincial Society, I485-I660 (Cambridge, 2008).

I5 Robertson and Gordon, Calendar, 26-3I.

I6 Erler, Ecclesiastical London, 97-8 and 37I-2, transcribing TNA C239/9/25(2); see also Lancashire, London Civic Theatre, iı6.

I7 John Coldewey, 'That Enterprising Property Player: Semi-Professional Drama in Sixteenth-Century England', Theatre Notebook 3I (1977), 5-I2; White, Drama and Religion in English Provincial Society, 22-4.

I8 Lancashire, London Civic Theatre, 69-II7, has a thorough account of dramatic activity by the London livery companies in the fifteenth and early sixteenth centuries, to be expanded in her forthcoming Records of Early English Drama volume on Civic London.

I9 Armourer' Account Book I497-I563 (Guildhall Library MS I2065/I), f. I22v. This volume is badly faded from water damage, but the entry involving players appears to date from the $1537-38$ fiscal year. This entry is cited by Lancashire, London Civic Theatre, 259ni30, though without quoting it or giving the date.

20 Guildhall Library MS I207I/I, p. II5, cited by Lancashire, 92.

2I Guildhall Library MS I2IO4, pp. 3-4.

22 Robert E. Burkhart, 'The Surviving Shakespearean Playhouses: The Halls of the Inns of Court and the Excavation of the Rose', Theatre History Studies I2 (1992), I73-92.

23 Peter J.A. Lubbock (ed.), The Halls of the Livery Companies of the City of London (Lavenham, Suffolk, 200I), IOo-3,

24 Susan Brigden, London and the Reformation (Oxford, 1989), 339.

25 Chambers, 'Dramatic Records', 288-9.

26 Paul Whitfield White, Theatre and Reformation: Protestantism, Patronage and Playing in Tudor England (Cambridge, 1993), 136.

27 Weavers' Ledger Book I489-I74I (Guildhall Library MS 4646), ff. 226, I7, transcribed in Francis Consitt, ed., The London Weavers' Company (Oxford, I933), I.255, 259; Founders' Record Book (Guildhall Library MS 6330/I), pp. 308, 3II, 314, 323 , 332, transcribed in Guy Parsloe (ed.), Wardens' Accounts of the Worshipful Company of Founders of the City of London 1497-168I (London, 1964), 99, IOO, I02, IO6, III. These records are also cited (but not quoted) by Lancashire, London Civic Theatre, 259 nizo.

28 Consit, The London Weavers' Company, I62-3. 
29 Ralph Hyde, John Fisher, and Roger Cline (eds), The A to $Z$ of Restoration London (London, 1992), 52.

30 See Lubbock, Halls of the Livery Companies of London, I40, and Parsloe, Wardens'Accounts, 86, 90-I, II9. The original deed by which the company purchased the property in I53I still survives in the Guildhall Library (MS 6357), but provides no useful information about its size.

3I Hyde, Fisher, and Cline, $A$ to $Z$ of Restoration London, 52.

32 Lubbock, Halls of the Livery Companies of London, I4O. In the I980s the company moved yet again, to their present hall on Cloth Fair in West Smithfield (personal communication from A.J. Gillett, clerk of the Founders' Company).

33 Journal i, f.4I and Journal v, f.68v, transcribed in Chambers, 'Dramatic Records', 286. Most of the records relating to tennis, bowling, and other pastimes are unpublished.

34 Chambers, 'Dramatic Records', 288; see also Glynne Wickham, 'Documents of control, I530-I660', in Wickham, Berry, and Ingram (eds), English Professional Theatre, 23 , item 7.

35 Cited in Wickham, 22.

36 B.W.E. Alford and T.C. Barker, A History of the Carpenters Company (London, 1968).

37 Acts of the Privy Council of England, ed. John Roche Dasent (London, I890), I.IO3-4, I09.

38 City of London Journal I5, f. 23v (London Metropolitan Archive COL/CC/or/or/or5). This record is mentioned by Lancashire (2002: 268n82), and will be fully transcribed by her in the forthcoming Records of Early English Drama volume on Civic London.

39 Chambers, 'Dramatic Records', 289; Brigden, London and the Reformation, 52.

40 The above-cited transcription in Chambers gives the second man's surname as 'Gadlowe', but it is clearly 'Tadlowe' in the original record

4I Tiffany Stern, "“On each Wall and Corner Poast”: Playbills, Title-pages, and Advertising in Early Modern London', English Literary Renaissance 36 (2006), 57-89, gives a thorough account of playbills in sixteenth- and seventeenth-century England, starting with a reference in a 1567 jest-book, to be discussed below.

42 David Kathman, 'Citizens, Innholders, and Playhouse Builders, I543-1622', Research Opportunities in Medieval and Renaissance Drama 44 (2005), 38-64, esp. 39-4I, provided a few basic facts about Blytheman, Tadlowe, and Hancock.

43 Gray was freed as a carpenter on 23 November 1535 after serving an apprenticeship with John King, and one of his apprentices, Anthony Browne, was freed posthumously as a carpenter in I544; see Bower Marsh (ed.), Records of the Worshipful Company of Carpenters, Vol. III: Court Book I533-I573 (Oxford, I9I5), 5, 6, I87. 
44 The will is Guildhall Library MS 9I7I/II, f.84, and the lawsuits, discussed below, are TNA CI/992/48 and CI/I064/57. Gray's will was not proved until 7 March I543, but he was dead by the previous December, as the second lawsuit cited here (which describes him as 'beerebrewer') makes clear.

45 W.G. Hoskins and R.A. McKinley (eds), A History of the County of Leicestershire: Volume 2 (Oxford, 1954), 36-9. The hospital, an Augustinian house, had been founded in the I2th century by Roger de Mowbray, and was suppressed between 1540 and I544.

46 A year earlier in I54I they were still living in St Sepulchre, where John Gray was assessed on Ioo marks of goods, a considerable amount; R.G. Lang (ed.), Two Tudor Subsidy Assessment Rolls for the City of London: I54I and I582 (London, I993), 82.

47 Drapers' Wardens' Accounts I508-I546 (MS +I43/W.A. 3). I am grateful to the Drapers' archivist, Penny Fussell, for looking up Chapman for me in Percival Boyd's index to the company's records.

48 These are TNA CI/992/48 and CI/IO64/57.

49 Guildhall Library MS 9I7I/II, ff. I95V-I96. The will was proved on I7 January I547, though Elizabeth Gray was dead by Io September, when Richard Hill appeared before the Testamentary Court regarding the will (Guildhall Library MS 9168/10, f. 26v).

50 The bill of complaint in TNA CI/992/48 describes the Green Dragon as being 'in Cowe lane in the parysshe of [Seynt] Sepulchre [wi]thout Newgate', immediately followed by an 'other messuage with ffowre[?] tenements A carpenters yard with thappurtenances to the same belongyng Sett \& lyeing in Cowe [Lane] aforesaid'. However, the document is damaged - the square brackets here represent interpolations where the text is missing - so we cannot be certain exactly what it originally said.

5I Hyde, Fisher, and Cline, The A to Z of Restoration London, 48, where Carpenter's Yard is $\mathrm{f}_{4} \mathrm{O}$.

52 There was another Northumberland Place in London, on Fenchurch Street in St Katherine Coleman parish, which was known as a bowling and gambling site for much of the sixteenth century.

53 Clothworkers' Hall, Clothworkers' Quarter and Renter Wardens' Accounts I520I558. I am grateful to Alex Buchanan, the Clothworkers' archivist, for allowing me access to the company's records. Blytheman does not appear in the quarterage list of I53I-32, but he was a freeman by 26 October 1532, when William Blytheman, citizen and 'clotheworker' of London, and two others bought the above-mentioned property from Richard Wray of Soberton, Hampshire, cousin and heir of John Wray, late of the king's household. See item A.I2I59 in A Descriptive Catalogue of Ancient Deeds in the Public Record Office, vol. V (London, 1906). 
54 Lang, Two Tudor Subsidy Assessment Rolls, 2, 4I, for the I54I assessment, and William McMurray, The Records of Two City Parishes (London, I925), 244-5, for the I536, I54I, and 1547 assessments in St Anne and St Agnes.

55 The early history of the building is summarized by C.L. Kingsford, 'Historical Notes on Medieval London Houses', London Topographical Record II (1917), 56-8.

56 See G.E. Cokayne and Vicary Gibbs (eds), The Complete Peerage, second edn (London, 1910-59), 9.720-22, and R.W. Hoyle, 'Percy, Henry Algernon, sixth earl of Northumberland (c.I502-I537)', Oxford Dictionary of National Biography, Sept 2004; online edn, Jan 2008 [<http://www.oxforddnb.com/view/article/21937>, accessed 22 July 2008].

57 On I8 January I544, the king granted the reversion by letters patent to John Skinner, who gained the right to a 4O-year lease once Paget's 2I-year lease ended. The 1534 lease and 1544 grant are described in the 1557 grant to Thomas Percy, cited below, and in a lawsuit by Edward Herenden (TNA E32I/20/5I).

58 TNA C66/926, m.I-2I (esp. 19), abstracted in Calendar of the Patent Rolls, Philip and Mary vol. IV, A.D. I557-I558 (London, 1939), 179-89.

59 See Katherine Panzer, A Short-Title Catalogue of Books Printed in England, Scotland, \& Ireland and of English Books Printed Abroad, I475-1640, vol. 3 (London, 1991), 98, 250.

60 Henry B. Wheatley, London, Past and Present, 3 vols. (London, I89I), I.300. Bryant Lillywhite's multi-volume typscript 'London Signs', deposited in the Guildhall Library in London, gives many details of the history of the Bull and Mouth. The former post office extension building is now (as of 2008) occupied by the London offices of Nomura Securtities.

6I Hyde, Fisher, and Cline, The A to $Z$ of Restoration London, 48 and 50, where Northumberland Place is A98.

62 The hall is mentioned in a I668 lease, specifying how the inn was to be rebuilt after being burned in the Great Fire. The lease is quoted in a 1693 Chancery lawsuit, Mayor of London etc. v. Stukeley (TNA C5/172/34), which is abstracted in McMurray, The Records of Two City Parishes, 159-60.

63 The jest is reprinted in Shakespeare Jest-Books: Reprints of the Early and Very Rare JestBooks Supposed to Have Been Used by Shakespeare, ed. W. Carew Hazlitt (London, I864), I45-7, and originally appeared in Mery Tales, Wittie Questions and Quicke Answeres, Very pleasant to be Readde, printed by H. Wykes in 1567.

64 A brief biography can be found in S.T. Bindoff, The House of Commons I509-I558 (London, 1982), 3.417-18.

65 Tadlowe gave his age as 65 in a Chancery deposition on 9 October 1553 (TNA C24/4I, part 2). Writs surviving in the National Archives show him lending £I296 to 2I dif- 
ferent creditors between 1525 and I53I, and almost certainly represents only a fraction of the total he lent. The amounts range from $£_{\mathrm{I} 2}$ (in $\mathrm{C}_{24 \mathrm{I}} / 279 / 6$ and $\mathrm{C}_{24 \mathrm{I}} / 28 \mathrm{O} / 2$ ) to $£ 300$ (in $\mathrm{C}_{24 \mathrm{I}} / 279 / 52$ ).

66 TNA Ci/9ro/r.

67 For the I532 rent accounts of the Minoresses without Aldgate, see below.

68 Lang, Two Tudor Assessment Rolls, 87 (for the I54I assessment); TNA Er79/145/174, sheets I4-I5 (for the I549 assessment); St Mary Woolnoth parish register I538-I64I (Guildhall Library MS 7635/I), transcribed in J.M.S. Brooke and A.W.C. Hallen (eds), The Transcript of the Registers of the United Parishes of S. Mary Woolnoth and S. Mary Woolchurch Haw, in the City of London, from their Commencement I538 to I760 (London, 1886). Brooke and Hallen list the St Mary Woolnoth churchwardens for each year, taken from the 1539-1599 Wardens' Accounts (Guildhall Library MS IOO2/IA).

69 Brigden, London and the Reformation, 497; J.A. Kingdon, Richard Grafton, Citizen and Grocer (London, 190I), 40; Bindoff, House of Commons, 3.417-18.

70 The quotations are from the I55I first edition (STC I8094). The 1556 second edition, published when Mary was on the throne, omits the Protestant flourishes and does not mention Tadlowe by name. Robinson was a former apprentice of Tadlowe's landlord and neighbor Sir Martin Bowes.

7I His will, dated 28 April I557, is TNA PROB II/39/168. The St Mary Woolnoth register records that on I2 May 1557 'was buried George Tadlowe haberdasher in the bodye of St Magnus Churche nighe to London bridge and died with in this parishe'. For Machyn, see John Gough Nichols (ed.), The Diary of Henry Machyn (London, I848), I36.

72 The rent accounts of the Minoresses without Aldgate show that Tadlowe was paying $£$ I2 annual rent in 1532 (TNA SC6/HENRYVIII/2I2I) and £I2 $3 \mathrm{~d}$ in I539 (SCII/955), and a post-dissolution document (SC 6/HENRYVIII/2396, f.I2v) shows that he continued to pay $£ 12$ to Bowes in 1540 . An English abstract of the grant to Bowes is in Letters and Papers of Henry VIII, I4.I.59I, and the original is TNA C66/686, m.I920.

73 Robert Latham and William Matthews (eds), The Diary of Samuel Pepys (Berkeley and Los Angeles, 2000), 5.330, 338; 7.63, 68.

74 See B85 in Hyde, Fisher, and Cline, The A to $Z$ of Restoration London, 55 and 74.

75 Howard Robinson, The British Post Office: A History (Princeton, 1948), 55.

76 John Strype, Survey of the Cities of London and Westminster and the Borough of Southwark, 2 vols. (London, I720), I.2.163; Thomas Pennant, Some account of London (Dublin, 179I), 456. The southern part of the White Horse site now lies under King 
William Street, created in the rgth century, and the northern part is occupied by a new 2Ist-century office building, with a 'Post Office Court' on the west side.

77 Hancock gave his age as 60 in a Chancery deposition on 7 December I559 (TNA $\mathrm{C}_{24} / 48 / 5$ ). His freedom is in Vintners' Freedom Book I428-1602 (Guildhall Library MS I $52 \mathrm{II} / \mathrm{I})$, f. $59 \mathrm{v}$.

78 The details are given in Kathman, 'Citizens, Innholders, and Playhouse Builders', 40-I. The relevant records are in Guildhall Library MS I52II/I, ff. 76, 76v, 78v, 8I, $82 \mathrm{v}, 84,84 \mathrm{v}, 87$, I03, II8v, II9.

79 Brooke and Hallen, Transcript, I, 2, 3, 4, 5, 179, I80, I83; Lang, Two Tudor Subsidy Assessment Rolls, 87; TNA EI79/145/174, sheets I4-I5; Brooke and Hallen, Transcript, xxxvii.

80 TNA C24/48/5, the same 1559 deposition cited above.

8I Fairly extensive histories of the Pope's Head (not including most of the I6th-century details described below) can be found in Kingsford, 'Historical Notes', 70-73, and Henry Lennox Hopkinson, Report on the Ancient Records in the possession of the Guild of Merchant Taylors of the Fraternity of St John Baptist in the City of London (London, 1915), 85-90.

82 Hustings Roll 238, no. 44 (London Metropolitan Archive CLA/o23/DW/or/238); TNA CI42/60/II2. The quotation is from the English abstract of Thomas Monoux's inquisition post mortem in George S. Fry (ed.), Abstracts of Inquisitiones Post Mortem Relating to the City of London, Part I, I485-I56I (London, I896), 52.

83 TNA PROB II/30/34. Kingsford, 'Historical Notes', 7I, mistakenly says that George Monoux's will was proved in 1548, rather than 1544. For the date of Monoux's death and other details, see Basil Morgan, 'Monoux, George (b. in or before I465, d. I544)', $O D N B$, online edn, Jan 2008 <http://www.oxforddnb.com/view/article/38558>.

84 Hustings Roll 247, no. 5I (London Metropolitan Archive CLA/o23/DW/or/246).

85 Ibid, no. 126 (London Metropolitan Archive CLA/o23/DW/or/246). In I540 John Willcock, a rabid Scottish reformer who denied the existence of purgatory and preached against confession, became curate at St Katherine Coleman, and in I546, Willcock's successor was brought before the privy council and accused of 'seducing' a servant of the Duke of Norfolk and of inciting his parishioners to iconoclasm (Brigden, London and the Reformation, 330, 400-402).

86 Brigden, 59I; Brooke and Hallen, Transcript, xx.

87 John Stow, A Survey of London, ed. Charles Lethbridge Kingsford, 2 vols. (Oxford, 1908), I.199.

88 Kingsford, 'Historical Notes', reproduces (between pages 72 and 73) a photograph of this ground plot, which is now in the archives of the Merchant Taylors' Company, who inherited it in I6Is from former lord mayor Sir William Craven. I am grateful 
to John Bayford, beadle of the Merchant Taylors, for allowing me to examine and photograph the original.

89 Kenneth Rogers, Old London: Cornhill, Threadneedle Street and Lombard Street, Old Houses and Signs (London and Tonbridge, 1935), reproduces two such photographs (facing p. I6 and facing p. II3). Pope's Head Alley was moved a few yards to the west during the construction of the Lloyd's building, so that the current alley (still called Pope's Head Alley) runs through the original site of the tavern.

90 Chambers, 'Dramatic Records', 291, transcribing Repertory xi, f. I35.

9I Ibid, 29I-2, 293, transcribing journal xv, ff. 24Ib-242, $244 \mathrm{~b}$.

92 Ibid, 293, transcribing Repertory xi, f. 315b.

93 E.K. Chambers, The Elizabethan Stage, 4 vols. (Oxford, 1923), 4.261, transcribing repertory xii.I, f. 92.

94 Curriers' Wardens' Accounts I556-9I (Guildhall MS I4346/I), ff. I7, 34, 47v, plus unfoliated pages. In I570-7I Wilkinson's widow was 'charged for her husband's quarterage while he lived'.

95 TNA PROB II/52/27I.

96 Chambers, The Elizabethan Stage, 4.26I, transcribing repertory xii.I, ff. Ioo and I62v.

97 This famous order is discussed most thoroughly by Ingram, The Business of Playing, II9-49. 